\title{
Okul Yöneticilerinin Yaptığı ve Yapmak İstediği İşler ile İş Doyumları Arasındaki İlişkinin İncelenmesi ${ }^{1}$
}

\author{
Prof. Dr. Selahattin TURAN* \\ Eskişehir Osmangazi Üniversitesi, Eğitim Fakültesi, Eskişehir / Türkiye \\ Gamze YALÇIN \\ Kızılören İlkokulu, Eskişehir / Türkiye
}

\section{$\ddot{\mathbf{O z}}$}

$\mathrm{Bu}$ araştırmanın amacı; Eskişehir ilinde görev yapan ilköğretim okul yöneticilerinin, görevlerinin ne olduğu ve ne olması gerektiği konusundaki görüşlerini belirlemek, bu görevleri nasıl yaptıkları ya da yaptırdıkları hakkında görüşlerini almak, okul yöneticilerinin yaptıkları ve yapmak istedikleri işler ile iş doyumu bileşenlerinden etkileşim, işin doğası, kurumun hedeflerinde açıklık ve prosedür arasındaki ilişkiyi; okul yöneticilerinin öğretmen, öğrenci, diğer çalışanlar ve çevresiyle nasıl bir etkileşim kurduğu, karşılaştığı sorunlara nasıl çözüm getirdiği konuları arasındaki ilişkinin ne düzeyde olduğunu belirlemektir. Araştırma bulgularına göre, eğitimde hizmet yılı ve yöneticilik yılı bakımından okul yöneticilerinin iş doyumlarında farklılaşmalar tespit

\footnotetext{
${ }^{1}$ Bu çalışma, 2015 yılında Eskişehir Osmangazi Üniversitesi Eğitim Bilimleri Enstitüsü’nde yapılan yüksek lisans tezi esas alınarak hazırlanmıștır.

* Sorumlu Yazar. Tel: +90222 $\quad$ Tes 23937 50/1612 E-posta:selahattinturan2100@ gmail.com

(C) 2015 Kalem Eğitim ve Sağlık Hizmetleri Vakfi. Bütün Hakları Saklıdır. ISSN: 2146-5606
} 
edilmiş ve okul yöneticilerinin yaptıkları ve yapmak istedikleri işler arasında anlamlı bir fark olduğu bulunmuştur. Bununla birlikte yaptıkları ve yapmak istedikleri işlerin alt boyutlarıyla iş doyumunun alt boyutları arasında farklı düzeylerde anlamlı ilişkiler olduğu tespit edilmiştir. Ayrıca okul yöneticilerinin işlerini çok çeşitli ve karmaşık bulmaları sebebiyle mevcut durumlarından memnun olmadıkları ve işlerinde iyileştirmelerin yapılması gerektiği sonucuna ulaşılmıştır. Okullarda niteliğin arttırılması için okul yöneticilerinin yaptıkları ve yapmak istedikleri işler arasındaki uçurumun ortadan kaldırılması ve okul yöneticilerinin iş doyumları arttırılarak öğrenme ve öğretme süreci ile ilgili işlere yoğunlaşmalarının sağlanması önerilmiştir.

Anahtar Kelimeler: Okul yöneticisi; İş doyumu; Etkileşim; İşin doğası; Kurumun hedeflerinde açıklık; Prosedür.

\title{
An Examination of the Relationship between Job Satisfaction and Works that School Principals Do and Want to Do
}

\begin{abstract}
The purpose of this study was to examine elementary school principals' thoughts about what their duties are and what their duties should be, to take view how they do their works or how they have works done, to reveal relationship between works that principals do and want to do and sub-dimension of job satisfaction (interaction, nature of job, clarity of institution's aims, procedure) and to define level of relationship between how school principals make relationship with teacher, students, staff and school environment and how they solve problems which they face. According to years of work and years of work as principal, some differences were found in school principals' job satisfaction. A meaningful relation was found between works that school principals do and want to do. Besides, meaningful relations in some different levels were found between sub-dimension of works that principals do and want to do and sub-dimension of job satisfaction. It was found that school principals find their job complicated and too much. So they were not satisfied with their job. To increase school quality, it is needed to remove distinction between what school principals do and what principal want to do and it is needed to have principals concentrate on learning and teaching process by increasing
\end{abstract}


school principals' job satisfaction.

Keywords: Principal; Job satisfaction; Interaction; Nature of the job; Clarity of institution's aims; Procedure.

\section{Extended Summary}

Schools need to achieve defined goals, respond to their members' expectations and to be administered effectively in every kind of organization which people put together (Aslanargun, 2014). Principals who work with these organizations should adjust themselves on developing dynamic situation. Therefore, principals are supposed to be mindful, producible, detecting problems correctly and deciding evenly in crisis situations (Çelikten, 2001, 2004). It is inevitable that today's school principals must do and know more than former school principals to react on issues that face on a daily basis (Baş, 2011). To give qualified and effective educationby schools to respond to the demands of society substantially depends on how school are administered. Hence, jobs that school principals are doing and taking responsibility affects education system directly.

\section{Purpose}

Schools can be accepted main output and service unit of an educational system. General purposes of education are to teach knowledge, abilities, intangible values and behavior in schools. Structure and action of school, the most functional parts of system, must suit with purpose and strategy of school (Sezgin, 2014). The most effective way to acquire this is school principals. School principals' job satisfaction proportion will affect school's structure and missions. Job satisfaction is very important for people's life and it affects positively 
people's success, productivity and connecting to group that they work in. Therefore, school principals' job satisfaction is very important to reduce schools' success. All schools' aim is to be successful. The same aim for all schools show us all school have got common characteristic structure. Beside this, differences between schools result from school principals. If all elements expect school principals in school are provided not to change, much behavior and thoughts would change depending on school principals (Açıkalın, 1998).

\section{Method}

This is quantitative research by taking views of the school principals to reveal the relationship between school principals do and want to do and sub-dimension of job satisfaction (interaction, nature of job, clarity of institution's aims, procedure). The main group composed of elementary school principals worked in Eskisehir in 2011-2012. There were 250 school principals in those years. It was accessed to reach 133 of them and survey was done accompanied by the searcher. Identify our job and job satisfaction surveys were used to collect data in this survey. To survey "School Principals Do and Want to Do" identify job survey that developed by Turan and Yücel (2006) was used by taking permission. To survey views of the school principals about job satisfaction which was developed by Spector (1997) and used by permission.

\section{Results}

Survey results are below according to what school principals do and what they want to do, sub-dimension of job satisfaction (interac- 
tion, nature of job, clarity of institution's aims, procedure) and years of work and years of work as principal.

1. The years school principals worked as principal $[\mathrm{F}(2-113)=3.748] p>.05$ and the years in education $[\mathrm{F}(2-113)=0.31] p>.05$ the year worked as principal with job they want to as principals $[\mathrm{F}(2-110)=1.064] p>.05$ and the years in education. There is no meaningful difference.

2. It shows that there is no meaningful difference about school principals' job satisfaction in education in term of service $[\mathrm{F}(2-115)=1.130] p>.05$ but there is meaningful difference between years worked as principal $[\mathrm{F}(2-115)=6.20] p=0.03$ $p<.05$. In other words, job satisfaction of school principals changes meaningfully according to their principal years. Between units to find differences through to groups, scheffe survey was applied. According to this survey results, it is defined that job satisfaction of principals worked 21-30 years $(\bar{x}=33.00, \mathrm{~S}=3.21)$ and $1-10$ years $(\bar{x}=31.85, \mathrm{~S}=3.96)$ is more than principals worked 11-20 years ( $\bar{x}=29.43, \mathrm{~S}=3.08)$.

To define meaning between job school principal do, sub-dimension of it and jobs which school principals want to do, sub-dimension of it, survey was used and results of it is below;

1. It was found that the approximate score of job including all elements that school principals do is $\bar{x}=6.39$ and the app- 
roximate score of jobs they want to do is $\bar{x}=8.13$. A meaningful increase was found in score $\mathrm{t}(102)=9.32, p<.01$.

2. The big huge difference score of sub-dimension is personal development. after that, these come successively; management, inspection, time management, evaluation, solving problems, providing parents and students pleasure and deciding.

According to the results between, jobs what school principals do and jobs what they want to, and interaction, nature of job, clarity of institution's aims, procedure;

1. It was found that there was a meaningful relationship between management inspection, personal development, solving problems, nature of job and jobs school principal want to do but there is no meaningful relationship between management inspection, personal development, solving problems, and jobs school principal do.

2. Clearly, there is meaningful relationship at aims of management and inspection which school principals want to do. However it is detected that there is no meaningful relationship between management and inspection, and jobs school principals do.

3. A high score wasn't detected for interaction and procedure through what school principals do and what they want to do.

4. It was detected that there is meaningful relationship with these; interaction and nature of job, clarity of institution's aims and nature of job, procedure and clarity of institutions. 


\section{Discussion and Conclusion}

It was found that school principals find their job complicated and too much. So they were not satisfied with their job. To increase school quality, it is needed to remove distinction between what school principals do and what principals want to do and it is needed to have principal concentrate on learning and teaching process by increasing school principals' job satisfaction. School principals need personal development, using their ability and produce new ideas but they have limited time to do these. Beside this, school principals want to find original solutions, find new ways and techniques in solving problems and be leader in their job totally without incidental upon routines. According to analysis results, a meaningful increase was seen in duties that principals want to do. This shows us what principals are doing now is different from what they want to do actually. It is expected from school principals to motivate teachers and students coming to school with low motivation and create a good school ambiance in management. In this survey, school principals expressed that they need to form a good relationship with their colleagues, have enough time for students and parents, make empathy abilities. Under the present circumstances, these expectations are not covered too much.

In working life, employees get positive sense when they get their expectations. This situation makes them have positive approach. We can name it as job satisfaction. If job satisfaction is low, it may cause absence in employees, disgusting, not obeying rules, complaining about job, damaging association, giving up job, fake illnesses and affect 
psychological system. Therefore, school principals 'job satisfaction should be increased and effect of school principals in school success should be taken into account.

\section{Giriş}

Bütün diğer kurum ve kuruluşlarda olduğu gibi okullar da önceden belirlenmiş belli amaçları gerçekleştirmeye, üyelerinin beklentilerini karşılamaya ve etkili bir şekilde yönetilmeye ihtiyaç duymaktadır (Aslanargun, 2014). Modern toplumlardaki sosyal, siyasî, kültürel ve ekonomik değişimlere paralel olarak, farklı kültür ve değerlere sâhip bireysel farkların ön plâna çıtı̆̆ı eğitim örgütlerinde sorunlar daha yoğun ve karmaşık yaşanmaktadır. Bu örgütlerde çalışan yöneticilerin de değişerek, gelişen dinamik yapıya ayak uydurması beklenir. Bu sebeple eğitim yöneticilerinin düşünebilen, üretebilen, problemleri doğru tespit edebilen ve çözme yeteneğine sâhip, her durumda etkili karar verebilen özelliklere sâhip olması beklenmektedir (Buluç, 2009; Çelikten, 2001, 2004; Keser ve Gedikoğlu, 2008).

Okul yöneticilerinin eskiye göre bugün daha çok şey bilmeleri ve yapmaları gerekmektedir (Baş, 2011). Okulların niteliği, nasıl yönetildiği ile ilişkilidir. $\mathrm{Bu}$ sebeple okul yöneticilerinin yaptıkları işler ve üstlendikleri sorumluluklar eğitimin niteliğini doğrudan etkilemektedir. Buradaki başarının temelini de okul yöneticilerinin işlerinden sağladıkları iş doyumu belirlemektedir. Okul yöneticilerinin işlerine bağlanmaları, işlerine devam etmeleri, işlerinden ayrılmaları; kısacası, işlerinde verimli olmaları ile iş doyumları arasında bir ilişki bulun- 
maktadır (Balc1, 1985, 2001; Nauman, 1993; Paknadel, 1995; Ronen, 1978; Yıldırım, 1999).

Okullar eğitim sisteminin temel üretim ve hizmet birimi olarak kabul edilebilir. Millî eğitimin genel ve özel amaçları ile temel ilkelerinin uygulama alanı okuldur. Okullarda kazandırılan bilgi, beceri, değer, tutum ve davranışları ile eğitim genel amaçları gerçekleştirilmeye çalışılır. Bu sebeple, sistemin en işlevsel parçası olan okulun, yapı ve işleyişi, amaç ve stratejisine uygun olmalıdır (Sezgin, 2014). Bunların sağlanmasındaki en etkili kişiler ise okul yöneticileridir. Okul yöneticileri okulların yap1 ve işleyişiyle ilgili üstlendikleri görevleri işlerinden sağladıkları doyum oranında daha etkili bir biçimde yerine getireceklerdir. İş doyumu, çalışanların hayatında önem taşımakta olup çalışanların işlerindeki verimliliklerini, başarılarını, çalıştıkları örgüte bağlılıklarını olumlu yönde etkilemektedir (Evcimen, 1998; Izgar, 2008). Bu sebeple okul yöneticilerinin iş doyumu düzeyleri okullar1mızın başarısını artırmada çok önemli bir etkendir.

Bütün okulların amaçları başarılı olmaktır. Okulların amaçlarının ortak olması, onların sadece yapısal yönden bir örnekliğini ortaya koymaktadır. Bunun dışında okulları birbirinden ayıran özellikler, okul yöneticisinden kaynaklanmaktadır. Okul yöneticileri dışında okuldaki bütün öğelerin değişmezliği sağlandığı zaman, okulda birçok durumun, davranışın ve düşüncenin okul yöneticisine bağlı olarak değiştiği gözlenebilir (Açıkalın, 1998; Başaran, 2000). Bu durum, okul yöneticisinin eğitim sistemi içindeki etkisini ve önemini bir kez daha ortaya koymaktadır. Okul yöneticilerinin üstlendikleri görev ve sorumluluklarının 
çeşitliliği ve çokluğu dikkate alındığında, işlerinin zor olduğu, sürekli olarak kendilerini geliştirmeleri ve yetiştirilmeleri gerektiği de ortadır.

Gelişmiş ülkelerde okul yöneticilerinin üstlendikleri birçok rolün ve görevin üstesinden etkili şekilde gelebilmeleri için, yetiştirilmelerine büyük önem verildiğini; birtakım yönetici standartları geliştirildiğini göstermektedir (Allen, 1998; Foley, 2001; Grogan ve Andrews, 2002; Lashway, 2003). Bu standartların oluşturulması için de öncelikle okul müdürlerinin yapmaları gereken görevler ve sahip olmaları gereken yeterlilikler ayrıntılarıyla belirlenmelidir.

\section{Yöntem}

\section{Araştırmanın Deseni}

Okul yöneticilerinin yaptıkları ve yapmak istedikleri işler ile etkileşim, işin doğası, kurumun hedeflerinde açıklık ve izlekler arasındaki ilişkiyi okul yönetici görüşlerine göre değerlendirmek amacıyla yapılan bu çalışma, nicel bir araştırmadır.

\section{Çalışma Grubu}

Araştırmanın çalışma grubunu 2011-2012 yılında Eskişehir il merkezinde İlköğretim okullarında görev yapan okul yöneticileri oluşturmaktadır. Örneklem olarak 250 ilköğretim okulu yöneticisine ulaşılabilmiştir. Yöneticilere bu çalışmaya katılmaları teklif edilmiştir ve 133 kişiden olumlu dönüt alınarak ölçek araştırmacılar eşliğinde cevaplandırılmıştır. Çalışma grubunun demografik özelliklerine ilişkin dağılımları aşağıdaki gibidir. 
Tablo 1. Okul Yöneticilerinin Hizmet Y1lları

\begin{tabular}{llllll}
\hline Seçenekler & $\mathbf{1}$ & $\mathbf{2}$ & $\mathbf{3}$ & Toplam \\
\hline Eğitimde hizmet y1lı & & $0-10 \mathrm{y} 1 \mathrm{l}$ & $11-20 \mathrm{y} 11$ & $21-30 \mathrm{y} 1 \mathrm{l}$ & \\
& $\mathrm{n}$ & 19 & 52 & 62 & 133 \\
& $\%$ & 14.3 & 39.1 & 46.6 & 100 \\
\hline Yöneticilik hizmet y1lı & & $0-10 \mathrm{y} 1 \mathrm{l}$ & $11-20 \mathrm{y} 11$ & $21-30 \mathrm{y} 1 \mathrm{l}$ & \\
& $\mathrm{n}$ & 84 & 37 & 12 & 133 \\
& $\%$ & 63.2 & 27.8 & 9 & 100 \\
\hline
\end{tabular}

\section{Veri Toplama Aracı}

Araştırmada veri toplama araçları olarak "İşimizi Tanıyalım" ve "İş Doyumu" ölçme araçları kullanılmıştır. Okul yöneticilerinin yaptıkları ve yapmak istedikleri işleri ölçmek üzere Turan ve Yücel (2006) tarafından geliştirilen "İşimizi Tanıyalım Ölçeğì" kullanılmıştır. Ölçek iki bölümden oluşmaktadır. Birinci bölümde okul yöneticilerine idarecilik yaparak kaç yıl geçirdikleri ve eğitimdeki hizmet yılları sorularına cevap vermeleri istenmektedir. İkinci bölümde ise 78 adet yöneticilikle ilgili ifadeler bulunmaktadır. Birinci sütunda başarılı bir müdürlük için bu ifadelerin ne derece gerekli olduğu sorularına cevap vermeleri gerekmektedir. Cevaplar 10'lu Likert tipindedir. Bu bölümde idarecilerin her bir soru için; aşırı lüzumsuz bir durum=1, çok lüzumsuz=2, hiç lâzım değil=3, pek lâzım değil, olsa da olur olmasa da=4, olursa zararı olmaz $=5$, olsa fena olmaz ama çok da âcil değil =6, biraz lâzım $=7$, buna oldukça ihtiyaç var $=8$, bunun olması çok lazım $=9$, aşırı düzeyde lazım, kesinlikle olmazsa olmaz bir şart=10 seçeneklerinden birini işaretlemeleri istenmektedir. İkinci sütunda ise yaptıkları işlerin ne düzeyde bu ifadeleri yansittıkları sorularına cevap vermeleri gerekmektedir. Cevaplar 10'lu Likert tipindedir. Bu bölümde idarecilerin 
her bir soru için; benim içinde bulunduğum ortamda aşırl düzeyde tam tersi söz konusu=1, benim şu ânki iş hayatımı hiç yansıtmıyor=2, benim iş hayatımda şu ânda böyle bir şey yok=3, çok nâdir, önemsenmeyecek kadar az=4, ara sıra bu durumu şu ânki iş hayatımda bu durum oluyor $=5$, çok sık olmasa da bazen oluyor bazen olmuyor $=6$, bu benim iş hayatımın son yllarında zaman zaman var diyebilirim $=7$, bu benim durumumu oldukça yansitıyor $=8$, bu benim şu ânki iş hayatımı çok yansitıyor=9, daha fazlası bile var, bu durum tamamen bizim okulda var olanı yansitıyor $=10$ seçeneklerinden birini işaretlemeleri istenmektedir.

Okul yöneticilerinin iş doyumunun alt boyutları olan etkileşim, işin doğası, kurumun hedeflerinde açıklık ve prosedüre âit görüşlerini ölçmek üzere Spector (1997) tarafından geliştirilen $\dot{I}_{s ̧}$ Doyumu Ölçeği izin alınarak kullanılmıştır. İş doyumu veri toplama aracı etkileşim, işin doğası, kurumun hedeflerinde açıklık ve prosedür olmak üzere dört alt boyuttan ve 4'lü Likert tipi olan toplam 16 sorudan oluşmaktadır. $\mathrm{Bu}$ bölümde okul yöneticilerinin her bir soru için kesinlikle katılıyorum (4), katıllyorum (3), klsmen katılıyorum (2), katılmıyorum (1) seçeneklerinden birini işaretlemeleri istenmektedir.

Veri toplama araçlarına Cronbach Alfa güvenirlik testi uygulanmıştır. İşimizi Tanıyalım veri toplama aracının yaptıkları işler bölümü toplam güvenirliği .979 'dur. Yapmak istedikleri işler bölümü toplam güvenirliği ise .958 'dir. Veri toplama aracının güvenirliği oldukça yüksek bulunmuştur. İ̧ Doyumu veri toplama aracının faktörlerinin Cronbach Alfa sayısı .463 ile .842 arasında değişmektedir. Top- 
lam Cronbach Alfa iç tutarlılık katsayısı ise 0.479 bulunmuştur. Yapılan güvenirlik testinden sonra veri toplama araçlarından anlaşılmasında sorun yaşanan maddeler tekrar düzenlenmiştir. Yöntem ve içerik konusunda gerekli görülebilecek geliştirmeler yapıldıktan sonra son şekilleri verilmiştir.

İşimizi Tanıyalım veri toplama aracının yapı geçerliliğinin belirlenmesi için faktör analizi yapılmıştır. Kaiser Meyer Olkin ve Barlett küresellik testleri sonucu $\mathrm{KMO}=.86$ ve $x^{2}=7.458$, $\mathrm{df}=1081, p<0.001$ bulunarak faktör analizinin uygunluğuna karar verilmiştir. 78 maddeden oluşan ölçekten; geçerlilik, güvenirlik ve faktör yüklerinin düşük olması sebebiyle 31 madde atılmıştır. Bunlar; 7, 14, 15, 16, 17, 18, 19, $20,21,23,24,34,35,36,37,38,39,40,41,44,45,48,55,57,59,60$, 61, 65, 66, 68 ve 75. maddelerdir ve geriye 47 madde kalmıştır. Mevcut durum sütununda bulunan faktörler, beklenen sütunu için de aynen kabul edilmiştir. Veri toplama aracının varimax rotasyonu sonucunda bu faktörlerin toplam varyansın \%78'ini açıkladığı saptanmıştır. Birinci faktör veri toplama aracına ilişkin toplam varyansın \%22'sini, ikinci faktör toplam varyansın \%14'ünü, üçüncü faktör toplam varyansın \%12'sini, dördüncü faktör toplam varyansın \%10’unu, beşinci faktör toplam varyansın \%8'ini, altıncı faktör toplam varyansın \%8'ini ve yedinci faktör ise toplam varyansın \%4'ünü açıklamaktadır.

Veri toplama aracına yapılan faktör analizi sonucu veri toplama aracının 7 alt boyuttan oluştuğu tespit edilmiştir. 7 faktörden oluşan 47 maddenin faktör yüklerinin .74 ile .92 arasında değiştiği gözlenmiştir. Faktörlerin öz değerleri 1.105 ile 24.280 arasında değişmektedir. Veri 
toplama aracının boyutları ve bu boyutların ölçüldügü maddeler aşağıdaki gibidir:

Yönetim ve denetim boyutu, $[\mathbf{7 8}, \mathbf{7 1}, \mathbf{7 2}, \mathbf{7 3}, \mathbf{7 0}, \mathbf{6 7}, \mathbf{7 6}, \mathbf{7 7}, \mathbf{7 4}$, $69,63,62,47,64,46]$

Zaman yönetimi boyutu, $[50,51,49,58,52,53,56]$

Karar verme boyutu, $[5,6,1,2,4,3,43]$

Değerlendirme boyutu, [30, 28, 29, 22, 42, 31]

Personel ve veli memnuniyetini sağlama, [26, 25, 33, 32, 27]

Kendini geliştirme, $[\mathbf{8 , 9}, \mathbf{1 0}, \mathbf{1 1}]$

Problem çözme, $[12,13,54]$

İ̧̧ Doyumu veri toplama aracının yapı geçerliliğinin belirlenmesi için faktör analizi yapılmıştır. Kaiser Meyer Olkin ve Barlett küresellik testleri sonucu $\mathrm{KMO}=.769$ ve $x^{2}=686.229$, $\mathrm{df}=78, p<0.001$ bulunarak faktör analizinin uygunluğuna karar verilmiştir.

On altı maddeden oluşan veri toplama aracına faktör analizi yapılmış ve 4 boyutlu olduğu tespit edilmiştir. 1, 3 ve 5 . maddeler atılmıştır ve geriye 13 madde kalmıştır. Varimax rotasyonu sonucunda bu faktörlerin toplam varyansın \%66'sını açıkladığı tespit edilmiştir. Birinci faktör veri toplama aracına ilişkin toplam varyansın \%20'sini, ikinci faktör toplam varyansın \%18'ini, üçüncü faktör toplam varyansın \%14'ünü ve dördüncü faktör ise toplam varyansın \%14'ünü açıklamaktadır. Analizler sonucu 4 faktörü oluşturan 13 maddenin faktör yüklerinin .48 ile .87 arasında değiştiği bulunmuştur. Faktörlerin öz 
değerlerinin ise 1.090 ile 4.789 arasında değiştiği saptanmıştır. Ölçeğin boyutları ve bu boyutların ölçüldüğü maddeler aşağıdaki gibidir:

\author{
Etkileşim, [2, 4, 6, 10, 14] \\ İşin doğası, $[7,12,15]$ \\ Kurumun hedeflerinde açıklık, $[8, \mathbf{1 1}, \mathbf{1 6}]$ \\ Prosedür, [9, 13]
}

\title{
Bulgular
}

Okul yöneticilerinin yaptıkları işlerin, yapmak istedikleri işlerin ve iş doyumlarının yöneticilik ve eğitimde hizmet yıllarına göre ANOVA testi analiz sonuçları aşağıda özetlenmiştir:

Okul yöneticilerinin yaptıkları işlerde yöneticilik yaptıkları yıllar $[\mathrm{F}(2-113)=3.748] p>.05$ ve eğitimde hizmet y1lları $[\mathrm{F}(2-113)=0.31]$ $p>.05$ ile yapmak istedikleri işlerde yöneticilik yaptıkları yıllar $[\mathrm{F}(2-110)=1.064] p>.05$ ve eğitimde hizmet y1lları $[\mathrm{F}(2-110)=.216]$ p>.05 bakımından anlamlı bir fark olmadığını göstermektedir.

Okul yöneticilerinin iş doyumlarının eğitimde hizmet yılları bakımından anlamlı bir fark olmadığını gösterirken $[\mathrm{F}(2-115)=1.130]$ $p>.05$, yöneticilik yaptıkları yıllar bakımından anlamlı bir fark olduğunu göstermektedir. Başka bir deyişle, okul yöneticilerinin iş doyumları yöneticilik yıllarına göre anlamlı bir şekilde değişmektedir. Birimler arası farkların hangi gruplar arasında olduğunu bulmak amac1yla yapılan Scheffe testinin sonuçlarına göre, 21-30 yöneticilik yılları arasında çalışan yöneticiler ( $\bar{x}=33.00, \mathrm{~S}=3.21)$ ve $1-10$ yöneticilik yılları arasında çalışan yöneticilerin $(\bar{x}=31.85, \mathrm{~S}=3.96)$ iş doyumlarının 
11-20 yöneticilik yılları arasında çalışan $(\bar{x}=29.43, \mathrm{~S}=3.08)$ yöneticilerden daha fazla olduğu belirlenmiştir.

Okul yöneticilerinin yaptıkları işler ve alt boyutları ile yapmak istedikleri işler ve alt boyutları ortalama puanları arasındaki farkın anlamlılığı için yapılan t Testi sonuçlarına göre; okul yöneticilerinin bütün maddeleri kapsayan yaptıkları işler bölümünden aldıkları ortalama puan $\bar{x}=6.39$ iken yapmak istedikleri işler bölümünden aldıkları ortalama puan $\bar{x}=8.13$ bulunmuştur. Yapmak istedikleri işlerdeki puanlarında anlamlı bir artma gerçekleşmiştir, $\mathrm{t}(102)=9.32, p<.01$. Alt boyutlarda aldıkları ortalama puanların da yapmak istedikleri işler bölümünde yaptıkları işlerden daha fazla olduğu görülmektedir. Aritmetik ortalamalar arasındaki en büyük fark alt boyutlardan kendini geliştirme arasında gözlenirken; ardından sırayla, yönetim ve denetim, zaman yönetimi, değerlendirme, problem çözme, personel ve veli memnuniyetini sağlama ve karar verme gelmektedir. 
Tablo 2. Paired t Test Analiz Sonuçları

\begin{tabular}{llllllll}
\hline Alt boyut & Değişken & $\mathbf{N}$ & $\overline{\boldsymbol{X}}$ & $\mathbf{S}$ & $\mathbf{S d}$ & $\mathbf{t}$ & $\boldsymbol{P}$ \\
\hline Yönetim ve & Yaptıları işler & 123 & 6.44 & 2.06 & 122 & 9.88 & .000 \\
Denetim & Yapmak istedikleri işler & 123 & 8.43 & 1.16 & & & \\
\hline Zaman & Yaptıkları işler & 128 & 6.43 & 2.11 & 127 & 9.76 & .000 \\
Yönetimi & Yapmak istedikleri işler & 128 & 8.38 & 1.21 & & & \\
\hline \multirow{2}{*}{ Karar Verme } & Yaptıkları işler & 132 & 5.58 & 1.88 & 131 & 7.26 & .000 \\
& Yapmak istedikleri işler & 132 & 6.66 & 1.56 & & & \\
\hline \multirow{2}{*}{ Değerlendirme } & Yaptıkları işler & 123 & 6.35 & 1.84 & 122 & 8.71 & .000 \\
& Yapmak istedikleri işler & 123 & 8.26 & 1.43 & & & \\
\hline Personel ve Veli & Yaptıkları işler & 133 & 7.22 & 1.64 & 132 & 9.44 & .000 \\
Memnuniyetini & Yapmak istedikleri işler & 133 & 8.71 & 1.32 & & & \\
Sağlama & Yaptıkları işler & 122 & 6.61 & 2.16 & 121 & 9.46 & .000 \\
\hline Kendini & Yapmak istedikleri işler & 122 & 8.71 & 1.28 & & & \\
Geliştirme & Yaptıkları işler & 130 & 6.60 & 1.92 & 129 & 8.84 & .000 \\
\hline Problem & Yapmak istedikleri işler & 130 & 8.11 & 1.57 & & & \\
Çözme & Yaptıkları işler & 103 & 6.39 & 1.64 & 102 & 9.32 & .000 \\
\hline Tüm & Yapmak istedikleri işler & 103 & 8.13 & 1.08 & & & \\
maddeler & & & & &
\end{tabular}

Okul yöneticilerinin yaptıkları ve yapmak istedikleri işler ile etkileşim, işin doğası, kurumun hedeflerinde açıklık ve prosedür arasındaki ilişkilere ait ilişki katsayısı sonuçlarına göre; okul yöneticilerinin yapmak istedikleri işlerden yönetim ve denetim, kendini geliştirme ve problem çözmenin işin doğasıyla anlamlı bir ilişkisi olduğu tespit edilirken; yaptıkları işlerden yönetim ve denetim, kendini geliştirme ve problem çözmenin anlamlı bir ilişkisi olmadığ miştir. Okul yöneticilerinin yapmak istedikleri işler yönetim ve denetimin kurumun hedeflerinde açıklıkla anlamlı bir ilişkisi olduğu tespit edilirken; yaptıkları işler yönetim ve denetimin anlamlı bir ilişkisi olmadığ1 tespit edilmiştir. Prosedür ve etkileşim alt boyutlarında ise yapmak istedikleri işlerin alt boyutlarının yaptıkları işlerin alt boyutla- 
rından yüksek katsayıda bir ilişki tespit edilememiştir. Etkileşimin işin doğasıyla, işin doğasının kurumun hedeflerinde açıklıkla, kurumun hedeflerinde açıklığın prosedürle anlamlı bir ilişkisi olduğu tespit edilmiştir.

\section{Sonuç ve Tartışma}

Okul yöneticilerinin yaptıkları işler oldukça karmaşık ve birbirleriyle iç içe geçmiş durumdadır. Yaptıkları herhangi bir iş birçok iş alanının kapsamına girebilmekte olup yaptıkları işlerin düzenli ve belirli bir zamanı da yoktur. Bu araştırmada, okul yöneticisinin yaptığı işler yedi kategoride toplanmıştır: Yönetim ve denetim, zaman yönetimi, karar verme, değerlendirme, personel ve veli memnuniyetini sağlama, kendini geliştirme ve problem çözme. Bu kategorilerin hepsinde, okul yöneticilerinin yaptıkları işlerle yapmak istedikleri işlerin birbirinden farklı olduğu tespit edilmiştir.

Okul yöneticilerinin yaptıkları işler ile yapmak istedikleri işler arasında anlamlı bir fark olup olmadığı birlikte incelenmiş ve yapmak istedikleri işler lehine anlamlı bir puan yükselmesi görülmüştür. $\mathrm{Bu}$ durum, okul yöneticilerinin yapmak istedikleri işlerin mevcut durumdaki yaptıkları işlerden farklı olduğunu göstermektedir. Müdürler, yaptıkları işlere ilişkin olarak gerekli gördükleri işlerin bazen olup bazen olmadıklarını ifade ederken, bu işlere aslında oldukça ihtiyaç duyulduğunu belirtmişlerdir.

Okul yöneticilerinin yönetim ve denetim alt boyutu için yaptıkları işler bölümünden aldıkları ortalama puan çok sık olmasa da bazen 
oluyor, bazen olmuyor iken yapmak istedikleri işler bölümünden aldıkları ortalama puan buna oldukça ihtiyaç var düzeyindedir. Zaman yönetimi alt boyutu için yaptıkları işler bölümünden aldıkları ortalama puan çok sık olmasa da bazen oluyor, bazen olmuyor iken yapmak istedikleri işler bölümünden aldıkları ortalama puan buna oldukça ihtiyaç var düzeyindedir. Karar verme alt boyutu için yaptıkları işler bölümünden aldıkları ortalama puan şu anki iş hayatımda bu durum ara sıra oluyor iken yapmak istedikleri işler bölümünden aldıkları ortalama puan olsa fena olmaz ama çok da acil değil düzeyindedir. Değerlendirme alt boyutu için yaptıkları işler bölümünden aldıkları ortalama puan çok sık olmasa da bazen oluyor, bazen olmuyor iken yapmak istedikleri işler bölümünden aldıkları ortalama puan buna oldukça ihtiyaç var düzeyindedir.

Personel ve veli memnuniyetini sağlama alt boyutu için yaptıkları işler bölümünden aldıkları ortalama puan bu benim iş hayatımın son yıllarında zaman zaman var diyebilirim iken yapmak istedikleri işler bölümünden aldıkları ortalama puan buna oldukça ihtiyaç var düzeyindedir. Kendini geliştirme alt boyutu için yaptıkları işler bölümünden aldıkları ortalama puan çok sık olmasa da bazen oluyor, bazen olmuyor iken yapmak istedikleri işler bölümünden aldıkları ortalama puan buna oldukça ihtiyaç var düzeyindedir. Problem çözme alt boyutu için yaptıkları işler bölümünden aldıkları ortalama puan çok sık olmasa da bazen oluyor, bazen olmuyor iken yapmak istedikleri işler bölümünden aldıkları ortalama puan buna oldukça ihtiyaç var düzeyindedir. 
Araştırma bulguları, okul yöneticilerinin kendilerini geliştirmeye, yeteneklerini kullanabilmeye ve yeni fikirler üretebilmeye oldukça ihtiyaç duyduklarını göstermektedir. Ayrıca rutin süreçlere bağlı kalmayıp özgün çözümler bulmak, problemlerin çözümünde yeni yol ve yöntemler keşfetmek istediklerini ve tam anlamıyla işlerinin liderlik yapma imkânı tanımasına ihtiyaç duyduklarını belirtmişlerdir. Okul yöneticileri, yöneticiliğin çalışanlara iyi hizmet sağlama imkânının olmasını, daha fazla takım çalışması yapabilmeleri gerektiğini ve böylece çalışanlarla iyi ilişki kurma, öğrencilere ve velilere yeteri kadar zaman ayırabilme, güven oluşturma becerilerine ihtiyaç duyulduğunu belirtmişlerdir. Mevcut durumda da bu beklentilerin az da olsa karş1landığını fakat yeterli seviyede olmadığını belirtmişlerdir. Okul yöneticileri yaptıkları işin öğretmenler, veliler, âmirler ve toplum tarafından daha çok takdir edilmesini istemektedirler. Ayrıca mevcut durumdan daha yüksek seviyede bağımsız olarak çalışabilmek, çalışma programlarını istedikleri gibi yapabilmek, zamanlarını kendi istedikleri gibi yönlendirip kullanabilmek ve yapacağ 1 işlere kendileri karar vermek istemektedirler.

Araştırma kapsamında okul yöneticilerinin yaptıkları işler ile yapmak istedikleri işlerin alt boyutlarıyla iş doyumuyla alt boyutlarıyla olan ilişkisi incelenmiştir. Okul yöneticilerinin yaptıkları işler yönetim ve denetim alt boyutunun; yaptıkları işler zaman yönetimi, karar verme, değerlendirme, personel ve veli memnuniyetini sağlama, kendini geliştirme ve problem çözme ile yüksek düzeyde, pozitif ve anlamlı bir ilişki olduğu saptanırken; yapmak istedikleri işler problem 
çözme alt boyutu ve izlekle ile düşük düzeyde pozitif ve anlamlı bir ilişki olduğu görülmektedir. Okul yöneticilerinin yapmak istedikleri işler yönetim ve denetim alt boyutunun; yapmak istedikleri işler zaman yönetimi, değerlendirme, personel ve veli memnuniyetini sağlama ve problem çözme ile yüksek düzeyde, pozitif ve anlamlı bir ilişki olduğu saptanırken; yapmak istedikleri işler karar verme alt boyutu ile orta düzeyde, pozitif ve anlamlı bir ilişki olduğu görülmüştür. Yaptıkları işler personel ve veli memnuniyetini sağlama, işin doğası ve kurumun hedeflerinde açıklık ile düşük düzeyde, pozitif ve anlamlı bir ilişki olduğu saptanmıştır.

$\mathrm{Bu}$ ve benzer araştırmalar, okul müdürlerinin yaptıkları işler ile yapmak istedikleri işler arasında büyük uçurumların olduğunu göstermektedir. Özge bir deyişle, müdürler okulla ilgili her türlü işle uğraşmakta ve her işi yapmaktadırlar. Bu ise müdürün aslî görevinden uzaklaşmasına sebep olmaktadır. Bu bağlamda, okul müdürlüğü ve yapması gereken aslî işlerin çağcıl gelişmeler 1şığında yeniden tanımlanması, yapılacak iş ile yetki arasındaki dengenin kurulması ve okul müdürlüğü atama ve yükseltme ölçütlerinin çağcıl araştırmalar ışığında nesnel bir şekilde yeniden tanımlanması, müdürlerin yaptıkları ve yapmak istedikleri işler ile ilgili daha etraflı nitel ve karşılaştırılmalı çalışmalar yapılması önerilebilir.

\section{Kaynakça}

Açıkalın, A. (1998). Okul yöneticiliği. Ankara: Pegem. 
Allen, J. (1998). A nation still at risk: An education manifesto. D. C.: CER.

Aslanargun, E. (2014). Eğitim örgütlerinde güç ve politika. S. Turan, (Ed.), Eğitim yönetimi teori, araştırma ve uygulama içinde (97-128). Ankara: PegemA.

Balcı, A. (1985). Eğitim yöneticisinin iş doyumu. Yayımlanmamış doktora tezi, Ankara Üniversitesi Sosyal Bilimler Enstitüsü.

Balc1, A. (2001). Etkili okul ve okul geliştirme: Kuram, uygulama ve araştırma. Ankara: Pegem A.

Baş, G. (2011). 21. Yüzyılda Eğitim Yöneticisinin Rolündeki Değişim ve Dönüşüm.

http://www.egitisim.gen.tr

Başaran, İ. E. (2000). Yönetim. Ankara: Ekinoks.

Buluç, B. (2009). İlköğretim okullarında bürokratik okul yapısı ile okul müdürlerinin liderlik stilleri arasındaki ilişki. Eğitim ve Bilim, 34(152), 71-86.

Çelikten, M. (2001).Okul Yöneticilerinin Problem Çözme Becerileri. Kuram ve Uygulamada Eğitim Yönetimi, 27, 297-309

Çelikten, M. (2004). Bir müdürün günlüğü. FÜ Sosyal Bilimler Dergisi, 14(1), 123-135.

Evcimen, S. H. (1998). Lise müdürlerinin iletişim düzeyi ile ögrretmenlerin iş doyumu ve öğrencilerle sinıf içi iletişim düzeyi arasındaki ilişkiler. Yayımlanmamış yüksek lisans tezi, Hacettepe Üniversitesi Sosyal Bilimler Enstitüsü. 
Foley, R. M. (2001). professional development needs of secondary school principals of collaborative-based service delivery models. High School Journal, 85(1), 10-23.

Grogan, M. ve Andrews, R. (2002). Defining preparation and professional development for the future. Educational Administration Quarterly, 38(2), 233-256.

Izgar, H. (2008).Okul yöneticilerinde iş doyumu ve örgütsel bağl1lık. Selçuk Üniversitesi, Ahmet Keleşoğlu Eğitim Fakültesi Dergisi, 25, 317-334.

Keser, Z. ve Gedikoğlu, T. (2008). Ortaöğretim okul müdürlerinin yetki ve sorumluluklarını kullanma derecelerinin belirlenmesi. Uluslararasi Insan Bilimleri Dergisi, 5(2), 1-23.

Lashway, L. (2003). Role of the School Leader: Trends and Issues. Journal of Curriculum and Supervision, 18(3), 240-58.

Nauman, E. (1993). Antecedents and concequences of satisfaction and commitments among expariate managers. Group Organization Managament, 18(2),153-188.

Paknadel, C. (1995). AIBB̈̈ ve ODTÜ'nün çeşitli fakültelerindeki ögretim elemanlarının iş doyumu. Yayımlanmamış doçentlik tezi, Abant İzzet Baysal Üniversitesi Sosyal Bilimler Enstitüsü.

Ronen, S. (1978). Job satisfaction and the neglected variable of job seniority. Human Relations, 31(4), 297-308.

Sezgin, F. (2014). Örgütsel Yap1. S.Turan, (Ed.), Eğitim yönetimi teori, araştırma ve uygulama içinde (43-94). Ankara: PegemA.

Spector, P. E. (1997). Job satisfaction: Application, assessment, causes, and consequences (Vol. 3). CA: Sage. 
Turan, S. ve Yücel, C. (2006, Nisan). Correlates in Work Contexts of Turkish Principalship. AERA. San Francisco, USA.

Yıldırım, Y. (1999). Sağlık Bakanlı̆̆ına bağlı genel hastanelerde çalışan hastane yöneticilerinin iş doyumu. Yayınlanmamış bilim uzmanlığ́ tezi, Hacettepe Üniversitesi Sağlık Bilimleri Enstitüsü. 